\title{
The interactive effects of climate change, riparian management, and a nonnative predator on stream-rearing salmon
}

\author{
David J. Lawrence, ${ }^{1,7}$ Ben Stewart-Koster, ${ }^{1}$ Julian D. Olden, ${ }^{1}$ Aaron S. Ruesch, ${ }^{2}$ Christian E. Torgersen, ${ }^{3}$ \\ Joshua J. Lawler, ${ }^{4}$ Don P. Butcher, ${ }^{5}$ and Julia K. Crown ${ }^{6}$ \\ ${ }^{1}$ School of Aquatic and Fishery Sciences, University of Washington, Seattle, Washington 98195 USA \\ ${ }^{2}$ Wisconsin Department of Natural Resources, Bureau of Water Quality, Madison, Wisconsin 53707 USA \\ ${ }^{3}$ USGS, Forest and Rangeland Ecosystem Science Center, Cascadia Field Station, Seattle, Washington 98195 USA \\ ${ }^{4}$ School of Environmental and Forest Sciences, University of Washington, Seattle, Washington 98195 USA \\ ${ }^{5}$ Oregon Department of Environmental Quality, Pendleton, Oregon 97801 USA \\ ${ }^{6}$ Oregon Department of Environmental Quality, Portland, Oregon 97204 USA
}

\begin{abstract}
Predicting how climate change is likely to interact with myriad other stressors that threaten species of conservation concern is an essential challenge in aquatic ecosystems. This study provides a framework to accomplish this task in salmon-bearing streams of the northwestern United States, where land-use-related reductions in riparian shading have caused changes in stream thermal regimes, and additional warming from projected climate change may result in significant losses of coldwater fish habitat over the next century. Predatory, nonnative smallmouth bass have also been introduced into many northwestern streams, and their range is likely to expand as streams warm, presenting an additional challenge to the persistence of threatened Pacific salmon. The goal of this work was to forecast the interactive effects of climate change, riparian management, and nonnative species on stream-rearing salmon and to evaluate the capacity of restoration to mitigate these effects. We intersected downscaled global climate forecasts with a local-scale water temperature model to predict mid- and end-of-century temperatures in streams in the Columbia River basin. We compared one stream that is thermally impaired due to the loss of riparian vegetation and another that is cooler and has a largely intact riparian corridor. Using the forecasted stream temperatures in conjunction with fish-habitat models, we predicted how stream-rearing chinook salmon and bass distributions would change as each stream warmed. In the highly modified stream, endof-century warming may cause near total loss of chinook salmon-rearing habitat and a complete invasion of the upper watershed by bass. In the less modified stream, bass were thermally restricted from the upstream-most areas. In both systems, temperature increases resulted in higher predicted spatial overlap between stream-rearing chinook salmon and potentially predatory bass in the early summer (two- to fourfold increase) and greater abundance of bass. We found that riparian restoration could prevent the extirpation of chinook salmon from the more altered stream and could also restrict bass from occupying the upper $31 \mathrm{~km}$ of salmon-rearing habitat. The proposed methodology and model predictions are critical for prioritizing climate-change adaptation strategies before salmonids are exposed to both warmer water and greater predation risk by nonnative species.
\end{abstract}

Key words: adaptation strategies; Bayesian hierarchical model; chinook salmon (Oncorhynchus tshawytscha); climate change; John Day River basin, Oregon, USA; nonnative species; range expansion; restoration; riparian land use; smallmouth bass (Micropterus dolomieu).

\section{INTRODUCTION}

Global climate change and a complex amalgam of other environmental stressors threaten to undermine the structure and function of freshwater ecosystems (Woodward et al. 2010). In stream systems, climate-related increases in water temperatures have already been widely observed (Kaushal et al. 2010, Isaak et al. 2012), and both the rate and magnitude of warming is predicted to increase as air temperatures rise over the

Manuscript received 23 April 2013; revised 26 August 2013; accepted 4 September 2013. Corresponding Editor: C. Nilsson.

${ }^{7}$ E-mail: david.lawrence@nfwf.org next century (Mote and Salathé 2010). Many streams are already highly altered by land-use-related removal of riparian vegetation that reduces stream shade and water use for irrigation that lowers flow, both of which make streams more susceptible to warming. As a result, elevated water temperature is one of the foremost water quality problems for rivers in the United States, and there are mounting concerns that climate-related warming will further intensify this problem (U.S. EPA 2002).

Climate-related stream warming will have direct, and in some cases, dramatic effects on populations of coldwater organisms such as salmon, many of which are already considered threatened or endangered as a 
result of a variety of human-related stressors (Ruckelshaus et al. 2002). Many salmonid species are expected to lose significant portions of their current distributions as thermally suitable habitat declines (Ruesch et al. 2012). For example, climate-change-induced stream warming is projected to result in the loss of almost half $(47 \%)$ of thermally suitable habitat for all trout in the interior western United States (Wenger et al. 2011). Salmon populations in increasingly warmer streams exist in fragmented systems that limit movement to thermally favorable environments. Habitat fragmentation may also prevent "rescue" effects from other more stable populations if parts of stream networks become unsuitable for migration (Rieman et al. 2007). The ultimate consequences of stream warming for salmon populations will vary by species and region, but the most dramatic effects are likely to be observed in areas that form the southern periphery of their range, where even small amounts of climate warming may push temperatures above the thermal tolerances of these species (Mantua et al. 2010, Beer and Anderson 2011).

Beyond the direct effect of thermally stressful temperatures, salmon must also cope with nonnative species, including warmwater predators that will expand into salmon-rearing areas as streams warm. However, with the exception of Wenger et al. (2011), most investigations of climate-change impacts on salmon have not considered fish-community interactions, or the potential interactive effects of invasive species and stream warming on salmon populations (Rahel and Olden 2008). Smallmouth bass (Micropterus dolomieu; bass hereafter), a predatory nonnative fish species that has been introduced throughout the range of salmon in the Pacific Northwest (Carey et al. 2011), may be particularly problematic for salmon populations faced with climate-warmed streams. Bass can consume large proportions of salmon runs (up to 35\%) under certain conditions, such as when small, subyearling chinook salmon (Oncorhynchus tshawytscha) co-occur with bass when water temperatures are warm enough to make bass metabolically active (Fritts and Pearsons 2004, Sanderson et al. 2009). Projections of bass range expansion under scenarios of climate change have been completed only for lake-dwelling bass (Sharma et al. 2009), and although bass occupy many salmon-bearing rivers, no previous study has forecast the upstream range expansion of stream-dwelling bass as streams warm. Although bass are generally considered a warmwater fish compared to salmon, our previous research has documented that bass and subyearling chinook salmon co-occur where upstream migrant bass overlap with the downstream range of stream-rearing chinook salmon (Lawrence et al. 2012). In situations where these species overlap, bass may prey on stream-rearing salmon directly or cause sublethal effects, such as reductions in the growth of subyearling salmon resulting from stress and the use of suboptimal habitats when bass are present (Kuehne et al. 2012).
In a changing climate, watershed managers are faced with the challenge of translating broadscale climate projections into anticipated local changes to determine where restoration actions could be undertaken to reduce potential impacts on salmon populations (Naiman et al. 2012). Translating regional climate forecasts to localscale predictions is a reoccurring need, and the gap between these scales leaves many managers with little guidance on how to adapt their present-day management efforts to climate change. Low-risk actions can be undertaken in the face of such uncertainty that would benefit a given system even if climate-change forecasts are not ultimately realized (Lawler et al. 2010, Rieman and Isaak 2010). Ultimately, managers need (1) a way to quantify how climate change may affect watersheds at multiple scales, and (2) decision tools to evaluate management actions that can offset the effects of future stream warming.

To bridge the science-management gap and gain knowledge of the interactive effects of multiple stressors in freshwater ecosystems, we studied how nonnative smallmouth bass, riparian land use, and climate change will act together to affect an evolutionary significant chinook salmon population in the John Day River (JDR) basin, a tributary of the Columbia River. To accomplish this task we combined downscaled regional climate-change forecasts of air temperature and streamflow with a fine-scale stream temperature model to determine future thermal regimes of streams in the JDR for mid- and end-of-century time periods. The stream temperature forecasts in turn were input to statistical fish-habitat models, developed from data within the study area, to forecast how habitat will change for stream-rearing salmon and to predict the upstream spread of nonnative bass into salmon habitat. We also explored the ability of riparian vegetation restoration to reduce climate-related warming in the JDR basin, and in turn, provide the dual conservation benefit of (1) maintaining rearing habitat for salmon in the face of stream warming, and (2) limiting the upstream invasion of predatory bass into salmon-rearing areas.

\section{Methods \\ Study area}

This study was conducted in the North Fork (NFJDR) and Middle Fork (MFJDR) tributaries of the John Day River (JDR; $21000-\mathrm{km}^{2}$ basin area), which collectively drain $6800 \mathrm{~km}^{2}$ and originate in the Blue Mountains of northeastern Oregon (Fig. 1). The JDR is of high conservation importance because it is one of the largest free-flowing rivers in the interior Columbia River basin. Both tributaries receive precipitation predominantly in the form of snow and rain in November through May. Snowmelt in late spring, typically peaking in April and May, causes high flows in the JDR basin that decline over June and July until the low flow summer period that occurs from August through September. Air temperatures within the study 
area range from winter lows of $-18^{\circ} \mathrm{C}$ to summer highs $>30^{\circ} \mathrm{C}$.

The NFJDR and MFJDR provide contrasting thermal conditions that allow for an assessment of the responses of subyearling chinook salmon and bass to climate and land-use-induced changes in stream temperatures. The NFJDR is a relatively cool system that flows through colluvial and alluvial canyons to alluvial valleys with gradients up to $30 \mathrm{~m} / \mathrm{km}(3.00 \%)$ in the upper basin to $2.4 \mathrm{~m} / \mathrm{km}(0.24 \%)$ in the lower section of the study area at elevations from $662 \mathrm{~m}$ (at the confluence of the MFJDR) to $1691 \mathrm{~m}$. The MFJDR is a tributary of the NFJDR and is warmer and less steep; it flows through alluvial canyons and valleys with a maximum gradient of $15 \mathrm{~m} / \mathrm{km}(1.50 \%)$ in the upper river to $0.6 \mathrm{~m} / \mathrm{km}$ $(0.06 \%)$. Elevations within the MFJDR study region are $662-1245 \mathrm{~m}$. Summer baseflow in both systems is provided by snowmelt-fed springs, which persist longer into the summer in the NFJDR. Although both tributaries have been altered due to land use and resource extraction, the riparian corridor of the NFJDR is largely intact because the North Fork John Day Wilderness Area and the Umatilla National Forest protect the upper NFJDR. Land adjacent to the lower NFJDR has experienced some removal of riparian vegetation due to livestock grazing. By contrast, land adjoining the MFJDR is mostly privately owned and has experienced significant riparian vegetation removal by grazing cattle; many parts of the river are wide and shallow as a result of bank erosion. Private landowners, The Nature Conservancy, the Confederated Tribes of the Warm Springs Nations, the Malheur National Forest, and the Oregon Department of Parks and Recreation are currently engaged in restoration projects to revegetate and re-meander parts of the upper MFJDR.

\section{Fish populations in the NFJDR and MFJDR}

The JDR supports the largest entirely wild run of chinook salmon in the Columbia River basin, and may serve as a source to chinook populations in the lower main stem Columbia River that are listed as threatened under the U.S. Endangered Species Act. Spring chinook salmon spawn in the upper NFJDR and MFJDR, and their offspring rear in these streams during their first year of life as subyearlings. The rearing and spawning habitat of chinook salmon has been increasingly constrained to the upper basins of both rivers due to thermal alterations related to land use (e.g., riparian vegetation removal) and water withdrawals for irrigation. Water temperatures throughout the NFJDR and MFJDR are often at or near the thermal tolerances for chinook salmon (Torgersen et al. 1999). Particularly warm years, such as 2007 and 2013, have caused mass mortality of adult chinook salmon that hold in pools of the MFJDR when maximum water temperatures exceed $28^{\circ} \mathrm{C}$ (e.g., 2007) or water temperature increases rapidly (e.g., 2013).

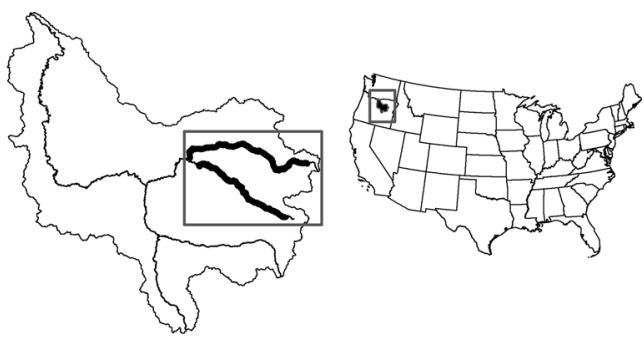

North Fork John Day River
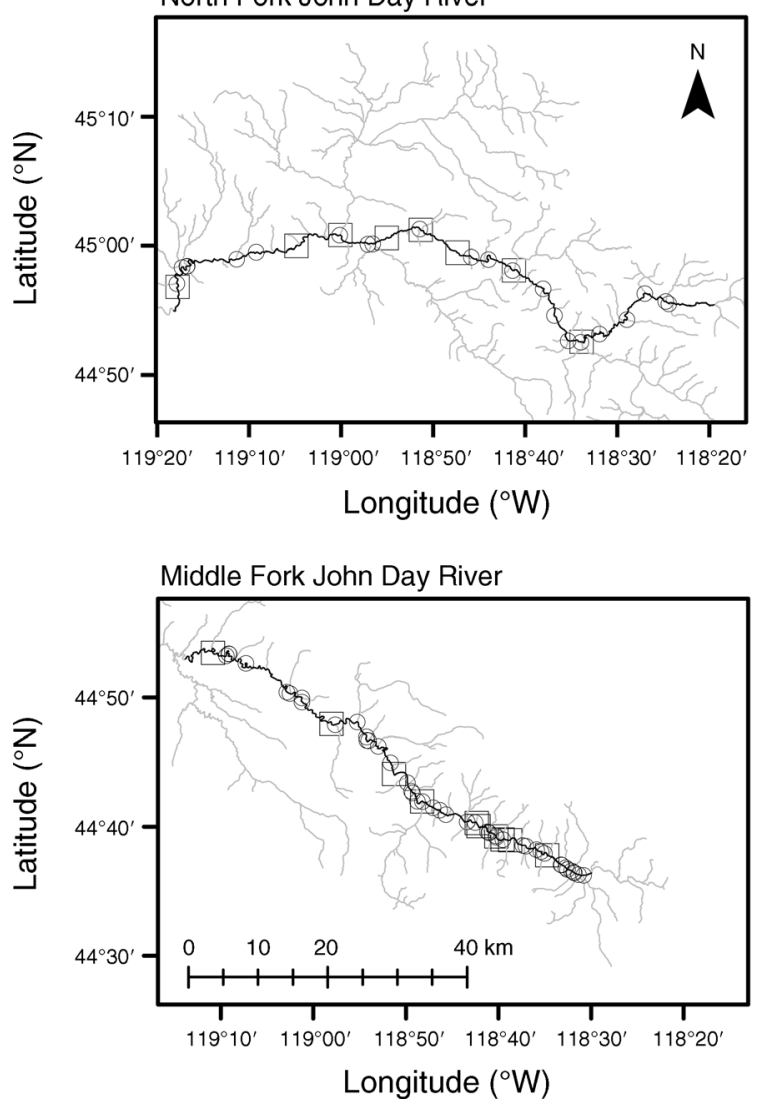

FIG. 1. Map of the North Fork (NFJDR) and Middle Fork (MFJDR) tributaries of the John Day River (JDR), which originate in the Blue Mountains of northeastern Oregon, USA, showing the extent of the model domain for each river (black line), the spatial position of modeled tributaries (i.e., the boundary conditions) where they intersect with the mainstem NFJDR and MFJFR (open circles), and the spatial location of the meteorological nodes where air temperatures were input (open squares).

At the downstream end of their distribution in the NFJDR and MFJDR, subyearling chinook salmon seasonally overlap with nonnative bass (Lawrence et al. 2012). Bass were introduced to the lower NFJDR in 1971 (Shrader and Gray 1999) but have subsequently moved upstream in both the NFJDR and the MFJDR. Bass move upstream and enter the lower (i.e., downstream) rearing areas of subyearling chinook salmon when water temperatures warm from June to August. 


\section{Modeling framework}

We linked a series of models to predict the distribution of bass and subyearling chinook salmon in response to stream warming caused by global climate change. First, we used global climate-change forecasts of air temperature and stream flow, downscaled to our study region as inputs into a local-scale water temperature model. This water temperature model was used to generate future forecasts of stream temperatures that were then input to bass and subyearling chinook salmon distribution models, which were based on observed fishtemperature relationships in the JDR basin. Our forecasts of future fish distributions were based on these relationships because water temperature determines the seasonal distribution of bass and chinook salmon in the JDR basin (Lawrence et al. 2012). Details on each of the individual models that compose this framework are provided here.

\section{Stream temperature modeling}

We used the mechanistic stream temperature model Heat Source (version 8.0.8; Boyd and Kasper 2003) to forecast stream temperatures resulting from climate change and various riparian vegetation restoration scenarios. This model uses high-resolution, spatially continuous landscape data, coupled with deterministic mass and heat-transfer processes to simulate water temperatures and flow dynamics. The Oregon Department of Environmental Quality (ORDEQ) produced a calibrated Heat Source temperature model of the NFJDR and MFJDR as part of a total maximum daily load (TMDL) assessment (ORDEQ 2010a). We employed the ORDEQ model but changed the air temperature inputs and boundary conditions (i.e., headwaters and tributary stream temperature and flow) to reflect downscaled climate-change predictions for these variables. Details on generating future air temperature and boundary condition forecasts in a form suitable for input to the Heat Source model are provided in Appendix A. All other variables were unchanged from the calibrated model (e.g., we assumed no change in riparian condition in response to changing flow). We chose to use Heat Source to model stream temperatures because it accounts for the spatially explicit role of vegetative shading in the determination of stream temperature, as well as the conditions upstream of each temperature prediction point. This allowed us to apply spatially explicit vegetation restoration scenarios to determine the capacity for management activities to offset stream warming caused by climate change.

\section{Climate data}

Climate forecasts were derived from the parallel climate model, version 1 (PCM1) general circulation model (GCM), which was used because it exhibited low bias for simulating observed climate for the region (Littell et al. 2011). We modeled a midrange forecast from 2030-2059 (hereafter referred to as the "2040" period), and an end-of-century period ranging from 2070-2099 (i.e., the "2080" period). For each period, the PCM1 GCM was run with a middle-of-the-road A1B greenhouse-gas emission scenario (IPCC 2007), which predicts a decline in energy production from fossil fuels and an asymptotic concentration (approximately 600 ppm) of atmospheric $\mathrm{CO}_{2}$ by the year 2100. GCM projections were downscaled to a $1 / 16^{\circ}$ resolution $(\sim 6$ $\mathrm{km}$ ) and a daily forecast using the spatially explicit delta method (Littell et al. 2011). This method extracts the historical variability in air temperature and precipitation and applies that variability to the future climate prediction. Downscaled PCM1 flow forecasts for NFJDR and MFJDR tributaries and the upstream boundary conditions were produced with a variable infiltration capacity model provided by Wenger et al. (2011) and Hamlet et al. (2010; details in Appendix A). Forecasts of daily boundary condition water temperatures were produced by parameterizing an independent nonlinear regression model relating forecasted air temperature to stream temperature at each model boundary (Appendix A). To compare future projections of warming to the present period, we calculated daily air temperatures and boundary conditions (i.e., water temperature and flow) over the 30-year period from 1977-2006. This period was chosen because it constrained the description of climate to the most current Pacific Decadal Oscillation shift that occurred in 1977 (Hamlet et al. 2007). Future climate predictions were calculated as daily means with the same variability that was observed in the present condition (i.e., 1977-2006).

\section{Model domains in space and time}

For the NFJDR, the model domain encompassed 120 river kilometers (RKMs), starting just above the confluence of the MFJDR with the NFJDR (RKM 53) to Baldy Creek (RKM 172) (Fig. 1). The model domain of the MFJDR contained 102 RKM, starting at RKM 12 and extending to RKM 113. These areas were chosen because they include the upstream extent of bass within each basin (Lawrence et al. 2012) and extend upstream where bass do not currently reside but may move as a result of climate-induced stream warming. Stream temperature was modeled from 15 June to 31 August in the NFJDR and from 1 May to 31 October in the MFJDR. The calibrated NFJDR model period was shorter due to ORDEQ time constraints when they originally developed the models (ORDEQ 2010a).

\section{Stream temperature model output}

We used a custom $\mathrm{R}$ script (version 2.13.0, R Development Core Team 2013) to convert the Heat Source water temperature output (generated at an hourly time step every $200 \mathrm{~m}$ along the stream) to mid- and end-of-century 7-day-average-daily (7DAD) mean water temperatures at a reach $(1 \mathrm{~km})$ scale in early and late summer. We modeled early- and late-summer distributions of bass and subyearling chinook salmon 
because these periods captured both the period of high potential overlap (i.e., early summer) and high potential for bass upstream movement (i.e., late summer; Lawrence et al. 2012). These periods also provided a contrast in temperature and flow conditions; during the earlysummer period (i.e., late June), the tributaries were on the declining limb of the snowmelt hydrograph, and thus discharge was high and water temperature was cool. In the late summer (i.e., early August), the streams were at base flow and usually at or near their peak water temperatures.

\section{Watershed restoration scenarios}

We investigated a range of restoration scenarios to determine the potential to mitigate climate-induced stream warming, limit the range expansion of bass, and minimize habitat loss for rearing chinook salmon within the JDR basin. The restoration approaches currently pursued in the basin (and in many river systems throughout the Pacific Northwest) include active or passive riparian restoration. Active restoration involves the replanting of overgrazed vegetation, whereas passive restoration is conducted by fencing off the riparian corridor to prevent livestock from grazing there and to allow the natural recruitment and regrowth of vegetation. The Heat Source model accounts for the spatially explicit role of vegetative shading in the heatbalance equation of the stream, and therefore, allowed us to simulate vegetation regrowth on the landscape and then determine its potential to cool the stream. Current vegetation was mapped every $50 \mathrm{~m}$ along the riparian corridor of the NFJDR and MFJDR from remote sensing imagery by ORDEQ as part of the Heat Source modeling process. The resulting GIS layer described the height of vegetation and its density, as well as its spatial position within $100 \mathrm{~m}$ of the river channel. An automated spatial analysis program sampled the vegetation layer to extract input for the Heat Source model, including vegetation height, basal elevation, density, and proximity to the stream (ORDEQ 2010a). Heat Source uses this information to determine the amount of shade that riparian vegetation provided every hour at each model distance step over the model temporal domain, accounting for the sun's position and shading provided by topography (e.g., canyons), termed "effective shade." ORDEQ (2010a) also estimated the "potential" vegetation along the riparian corridor of the NFJDR and MFJDR, i.e., the vegetation that would be present without human and livestock impacts. The process of estimating potential vegetation is summarized in Appendix $\mathrm{C}$, and full details of the restored vegetation characteristics are described in ORDEQ (2010b).

Because complete restoration of the riparian corridor is unlikely, we tested restoration of riparian habitat across a range of management scenarios. To prioritize those areas of the river that should be restored first, we ran the Heat Source model using the current vegetation configuration and in the fully restored condition, and then calculated the difference (i.e., the potential effective shade) between shade provided under the current condition of the riparian corridor and shade provided under a fully restored vegetation scenario. Potential effective shade was determined on $15 \mathrm{July}$, the warmest day of the model calibration year (2002). In an effort to compare realistic restoration segment sizes, we aggregated the $50-\mathrm{m}$ reaches into $600-\mathrm{m}$ segments, which are typical of fencing projects in the basin, based on 91 projects from 1984-2008 (Powell et al. 2008). These restoration segments were compared by averaging the potential effective shade across the 12 finer-scale $(50 \mathrm{~m})$ reaches that composed the broader segment; then segments were arranged from high to low in terms of their potential to increase the shade of the stream. The area encompassing the North Fork John Day Wilderness area (RKM 120.3-164.1) has relatively unimpacted vegetation and therefore was not considered for potential restoration within this study. This aggregation scheme resulted in a total of 129 segments in the NFJDR and 169 segments in the MFJDR. We ran scenarios where we restored the top 5, 10, 20, 30, 40, 50, 60, 70, 80, 90 , and $100 \%$ of restoration segments, and we compared the thermal profile of the river under these different scenarios in the 2080s. Additionally, we compared the potential to reduce warming as a result of climate change given a more "opportunistic" restoration scenario by randomly choosing the same percentages of segments without regard for their potential effective shade. This method simulated restoration that is conducted where it is feasible due to land availability or other social constraints. Although it would have been desirable to prioritize restoration by running all potential combinations of restoration segments and determining those combinations that would most effectively lower the stream temperature, the run time of the model (three to five hours) and number of potential simulations (the factorial of $129+169$ segments) were not feasible with our computing resources.

\section{Fish distribution models}

Bass and subyearling chinook salmon distribution models were built based on fish and habitat surveys conducted in late June and early August of 2009 (MFJDR and NFJDR) and 2010 (NFJDR only; Lawrence et al. 2012). Lawrence et al. (2012) revealed that bass abundance in the study area had a positive, nonlinear relationship to water temperature at a broad scale, and if satisfactory temperatures were available, greater water depths were (linearly) associated with greater bass abundance. For this study, we built a Bayesian hierarchical model to quantify this hierarchical habitat selection at two spatial scales. At a broad "segment" scale, we used temperature as a predictor of bass abundance, and within segments, we used depth as a predictor at a finer 1-km "reach" scale. 
We delineated the two spatial scales using constrained hierarchical clustering, which is similar to ordinary hierarchical clustering with the additional constraint that objects can be agglomerated only if they are contiguous (Gordon and Birks 1972). The goal was to define segments (3 $\mathrm{km}$ in length or greater) that contained reaches (defined here as $1 \mathrm{~km}$ ) with similar geomorphic and thermal characteristics. Clustering of individual $(1 \mathrm{~km})$ reaches into segments was based on contributing watershed area $\left(\mathrm{m}^{2}\right)$, average channel width $(\mathrm{m})$, and average stream temperature, as measured from airborne thermal infrared (TIR) remote sensing (Torgersen et al. 2001). The TIR data set was provided by ORDEQ (2010a) and represents approximate maximum summer temperature. The TIR dataset was employed because it captured small-scale spatial variation in surface water temperature (e.g., thermal anomalies associated with springs, groundwater input, and hyporheic exchange). Watershed area was determined from Netmap (available online). ${ }^{8}$ Channel width was measured in August 2010 during the fish distribution survey (Lawrence et al. 2012). Clustering was carried out based on a column-standardized Euclidean distance matrix calculated with the CONISS agglomerative clustering method (Grimm 1987) in $\mathrm{R}$ with the rioja package (Juggins 2012). Segments in the NFJDR $(n=10)$ and $\operatorname{MFJDR}(n=9)$ ranged in length from 3 to $10 \mathrm{~km}$ and were defined according to spatial patterns in channel geomorphology (e.g., channel width and major tributary confluences) and stream temperature.

The hierarchical model for bass abundance had a nonlinear model to quantify the segment-scale relationship with temperature and a linear model to quantify the reach-scale relationship with depth. At the reach scale, estimated abundance was assumed to follow a Poisson distribution, and the rate parameter was a linear function of mean abundance in the segment and the average maximum depth

$$
\begin{aligned}
& y_{i j} \sim \operatorname{Poisson}\left(\lambda_{i j}\right) \\
& \lambda_{i j}=\bar{y}_{j}+\beta \times \operatorname{depth}_{i j}
\end{aligned}
$$

where $y_{i j}$ is the observed bass abundance in the $i$ th reach of the $j$ th segment, $\lambda_{i j}$ is the rate parameter of the Poisson distribution, $\bar{y}_{j}$ is the mean abundance at the $j$ th segment, and $\beta$ quantifies the relationship between reach-scale (average maximum) water depth and deviations from the segment mean abundance. Reach-scale depth, depth ${ }_{i j}$, was mean centered within each segment. At the segment scale, mean bass abundance was assumed to be normally distributed, dependent on segment-scale water temperature. The relationship between bass abundance and temperature at the segment scale was estimated using a logistic equation

\footnotetext{
${ }^{8}$ www.netmaptools.org
}

$$
\begin{aligned}
\bar{y}_{j} & \sim N\left(\mu_{j}, \tau_{y}\right) \\
\mu_{j} & =\frac{K}{1+n_{0} \times e^{-r \times \text { temp }_{j}}}
\end{aligned}
$$

where $\bar{y}_{j}$ is the mean abundance at segment $j ; \mu_{j}$ and $\tau_{y}$ are the mean and precision of the normal distribution, respectively; $K, n_{0}$, and $r$ are the parameters of the logistic equation; and temp $\mathrm{p}_{j}$ is the average 7DAD (7day-average-daily) mean temperature of all reaches within segment $j$. Temperature data were derived from water temperature loggers deployed during the fish surveys over the model longitudinal extent (Lawrence et al. 2012) and were centered based on the mean and scaled by the standard deviation across the study region. We choose to model the 7DAD mean because it represents the central tendency of temperature and is biologically relevant to bass and subyearling chinook. The following "uninformative" prior distributions were used to specify the likelihood structure (Gelman et al. 2004):

$$
\begin{aligned}
\beta \sim N\left(0, \tau_{\beta}\right) & \tau_{y} \sim \Gamma(1,0.1) \\
\tau_{\beta} \sim \Gamma(1,0.1) & K \sim \Gamma(2,0.5) \\
n_{0} \sim \Gamma(2,0.5) & r \sim \Gamma(2,0.5) .
\end{aligned}
$$

The model was fitted in WinBUGS version 1.4.3 (Lunn et al. 2000) called from R with the R2WinBUGS package (Sturtz et al. 2005). Separate early-summer and late-summer models were developed to describe the relationship between bass and temperature. Each model had the same structure but was fitted with data collected from early- and late-summer bass distribution surveys (Lawrence et al. 2012). Model performance was measured using pseudo- $R^{2}$ values, which were 0.73 for the early-summer model, and 0.71 for the late-summer model. No spatial autocorrelation was detected in the model residuals. To predict the future spatial distribution of bass, we used the 7DAD mean water temperatures forecasted for early and late summer of the 2040s and 2080s in the fitted Bayesian hierarchical model, and then obtained the median of the posterior predictive distribution of bass abundances per reach (e.g., Boone et al. 2012).

To forecast how the availability of salmon-rearing habitat in the NFJDR and MFJDR may change by the 2040s and 2080s, we fitted a model to relate subyearling chinook salmon distribution to stream temperature. The subyearling chinook salmon model was based solely on temperature. Therefore, we used logistic regression (Hosmer and Lemeshow 2000) with 7DAD mean water temperature to develop a species distribution model at the reach scale $(1 \mathrm{~km})$ that used observations of subyearling chinook salmon in the JDR basin from Lawrence et al. (2012). The model fitted in $\mathrm{R}$ had an area-under-the-curve (of the receiver operator characteristic curve) of 0.89 . Unlike the bass model, where we 
fitted separate early- and late-summer models, we fitted only one subyearling chinook salmon model with data from late summer. In this case, we were primarily interested in defining thermally suitable habitat for subyearling chinook salmon, but water temperatures in the early-summer surveys (i.e., in 2009 and 2010) were not warm enough to observe thermal restrictions in their distribution. However, we postulated that early-summer temperatures in 2040 and 2080 may be warm enough to restrict subyearling chinook salmon from occupying parts of the NFJDR and MFJDR. To predict the future spatial distribution of subyearling chinook salmon in early and late summer, we applied stream temperature forecasts to the fitted regression model and reported the probability of salmon presence over the longitudinal extent of the models.

\section{RESUlts}

Water temperatures in both of the studied tributaries are forecasted to increase as air temperatures rise and discharge changes over the next century. The 7-dayaverage-daily (7DAD) mean water temperature of the North Fork of the John Day River (NFJDR) in the early summer is forecasted to increase $1.2^{\circ} \mathrm{C}$ by 2040 and $2.3^{\circ} \mathrm{C}$ by 2080 (averaged over the longitudinal profile of the river, relative to the 30 -yr norm of temperatures in the current condition; Appendix B). In the late summer, 7DAD means in the NFJDR are projected to increase $1.5^{\circ} \mathrm{C}$ by 2040 and $2.0^{\circ} \mathrm{C}$ by 2080 . An average increase of $1.6^{\circ} \mathrm{C}$ by 2040 and $3.2^{\circ} \mathrm{C}$ by 2080 is predicted for the MFJDR in the early summer, and increases of $1.1^{\circ} \mathrm{C}$ by 2040 and $1.7^{\circ} \mathrm{C}$ by 2080 are predicted in the late summer. In terms of absolute temperature, forecasted 7DAD mean water temperatures of the Middle Fork of the John Day River (MFJDR) exceed estimates for the NFJDR.

\section{Bass abundance and upstream extent}

As stream temperatures warm, bass are predicted to move upstream in both the NFJDR and MFJDR relative to their distribution in 2009 (Figs. 2 and 3). For example, the upstream extent of bass in the NFJDR in early summer was at river kilometer (RKM) 76.7 (modeled, RKM 75; Fig. 2A) but is forecasted to increase to RKM 91 by 2040 (Fig. 2B) and RKM 114 by 2080 (Fig. 2D). Bass upstream extent increased between early and late summer in 2009 (from RKM 76.7 to 99.7; modeled, RKM 96; Fig. 2A, F), and similarly, bass are forecasted to move farther upstream in the late summer period as the stream warms. By 2040, bass are forecasted to move an additional $29 \mathrm{~km}$ upstream (to RKM 125 compared to RKM 96; Fig. 2G) in the late summer; by 2080, bass are predicted to move up to RKM 132 (a total of $36 \mathrm{~km}$ compared to the 2009 modeled upstream extent; Fig. 2I). Larger increases in upstream distribution are forecasted for the MFJDR where the entire upstream extent of the river is forecasted to be thermally suitable for bass by 2040 in both early and late summer
(Fig. 3B, G). This represents an overall increase in upstream extent of $67 \mathrm{~km}$ in the early summer and 48 $\mathrm{km}$ in the late summer by 2040 .

In both systems, bass abundance is predicted to increase in 2040-2080 (Figs. 2 and 3). In the NFJDR, 2080 forecasts of early-summer abundance of bass are at or near carrying capacity ( $K$ in the model) in $38 \mathrm{~km}$ (RKM 53-90; Fig. 2D), and late-summer bass abundance is variable but near carrying capacity in $62 \mathrm{~km}$ (RKM 53-114; Fig. 2I). The early-summer forecast of bass abundance for 2080 in the MFJDR shows a similar trend; however, bass reach the carrying capacity over a longer stretch of river (97 km; RKM 12-108; Fig. 3D) due to higher forecasted water temperatures. In late summer, bass abundance is near carrying capacity in 69 $\mathrm{km}$ in 2080 (RKM 12-80; Fig. 3I).

\section{Probability of subyearling chinook salmon presence}

The probability of subyearling chinook salmon presence is negatively related to water temperatures. Therefore, as water temperatures increase, the availability of chinook salmon rearing space decreases. In both seasons and both tributaries, subyearling chinook salmon are forecasted to have a lower probability of presence by the 2040s and 2080s (Figs. 2 and 3). In the NFJDR, the probability of presence in the early summer remains high $(P>0.8)$ by the 2040 s (Fig. $2 \mathrm{~B})$, and this is sustained by the 2080s, although their probability of presence is somewhat reduced below RKM 90 (Fig. 2D). In the contemporary climate (i.e., 2009), the rearing space available to subyearling chinook salmon decreased between early and late summer as a result of seasonal warming (Fig. 2A, F), but this seasonal reduction is greater in 2040 and 2080 (Fig. 2B vs. 2G; Fig. 2D vs. 2I). If we define thermally suitable habitat for subyearling chinook salmon as areas where their probability of presence is $\geq 0.5$ (which corresponds to $19.5^{\circ} \mathrm{C}$ in our model), then thermally suitable habitat in the NFJDR during late summer occurs upstream of RKM 98 in 2009 (Fig. 2F), RKM 126 in 2040 (Fig. 2G), and RKM 132 in 2080 (Fig. 2I).

The MFJDR is warmer than the NFJDR (Appendix B) and currently has a lower probability of subyearling chinook salmon presence. However, the additional warming forecasted for 2040 and 2080 may result in an even greater loss in rearing habitat in the MFJDR (Fig. 3). In the early summer, thermally suitable habitat for subyearling chinook salmon was found throughout the MFJDR in 2009 (RKM 12-112; Fig. 3A) but only occurs upstream of RKM 26 in 2040 (Fig. 3B) and RKM 73 in 2080 (Fig. 3D). In late summer, thermally suitable chinook salmon habitat occurred upstream from RKM 57 in 2009 (Fig. 3F) but only occurs in 4 $\mathrm{km}$ by the 2040s (RKM 96-99; Fig. 3G) and in $0 \mathrm{~km}$ by the 2080s (Fig. 3I). In 2009, the probability of occurrence for subyearling chinook salmon in late summer was $>0$ throughout the MFJDR (Fig. 3F), whereas by 2080 , probability of presence exceeded 0 


\section{Early summer}
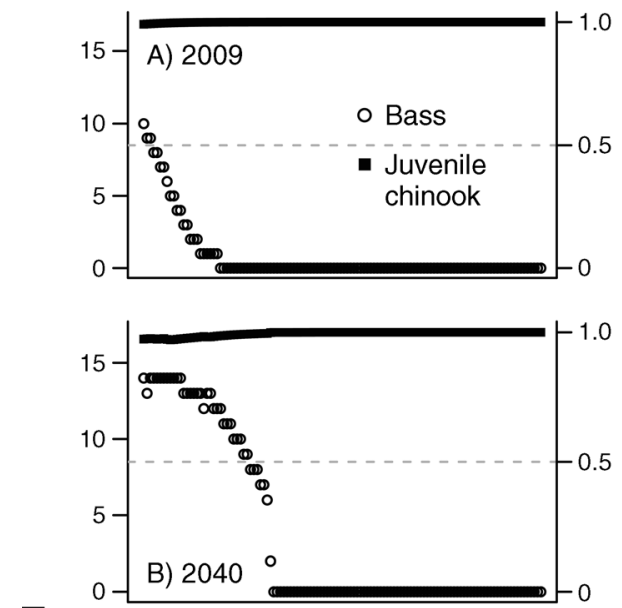

$\sum$
$\frac{1}{0}$
$\frac{1}{1}$
0
0
0
$\frac{1}{0}$
$\frac{0}{0}$
$\frac{1}{5}$
00
0
0
0
0
0
0
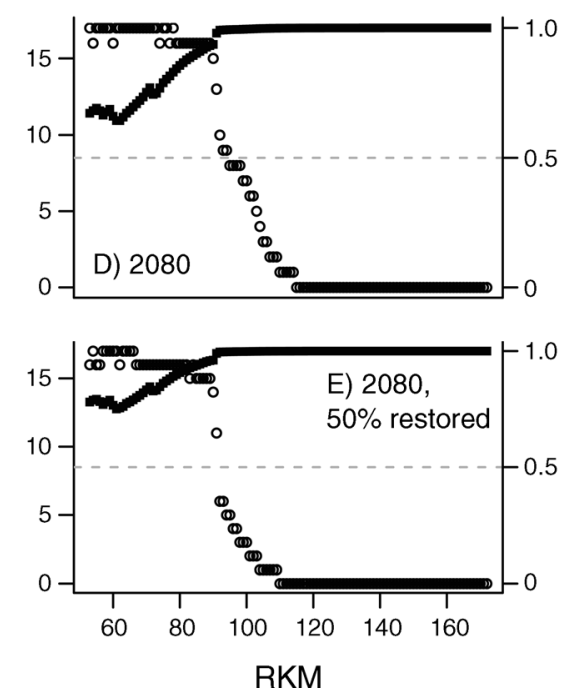

Late summer
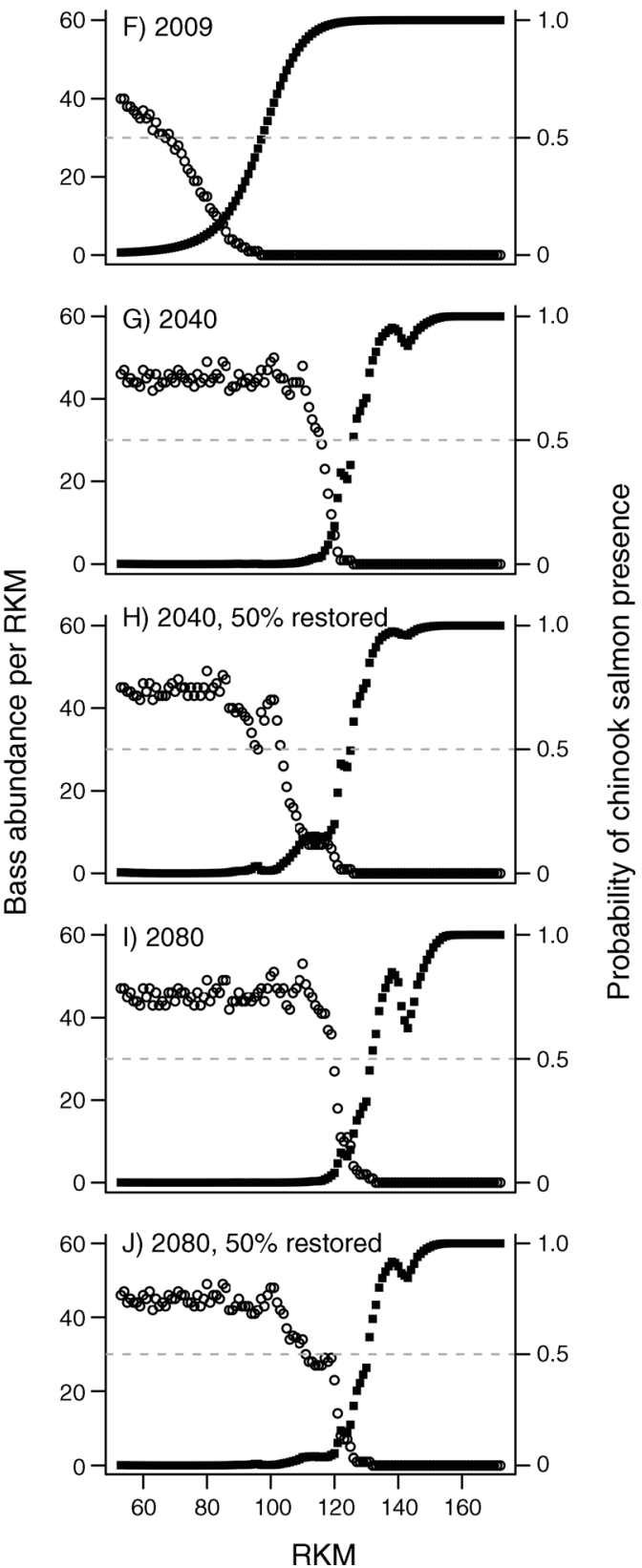

FIG. 2. Modeled bass and subyearling (juvenile) chinook salmon distribution over the longitudinal profile of the NFJDR in early summer (A) 2009, (B) 2040, (C) 2040 with the top 50\% of segments restored, (D) 2080, and (E) 2080 with the top $50 \%$ of segments restored; and late-summer forecasts in (F) 2009, (G) 2040, (H) 2040 with the top 50\% of restoration segments restored, (I) 2080 , and (J) 2080 with the top $50 \%$ of restoration segments restored. The 2009 bass distributions, rather than a $1977-2006$ average, are shown because bass have expanded in the study area over that period, and 2009 represents the most up-to-date known spatial distribution of bass. The dashed gray line in each panel indicates the probability that subyearling chinook salmon presence equals 0.5. RKM signifies river kilometer.

only in the upper $33 \mathrm{~km}$ of the MFJDR in the late summer, with a maximum probability of 0.38 (Fig. 3I).

\section{Bass and subyearling chinook salmon overlap}

As water temperatures warm by 2040 and 2080, the overlap between bass and subyearling chinook salmon may increase substantially in the early summer (Figs. 2B, D and 3B, D), but may show only limited change in the late summer (Figs. 2G, I and 3G, I). If overlap is defined as $1-\mathrm{km}$ reaches where bass abundance $\geq 1$ and the probability of subyearling chinook salmon presence is $\geq 0.5$, then the total early-summer overlap between 

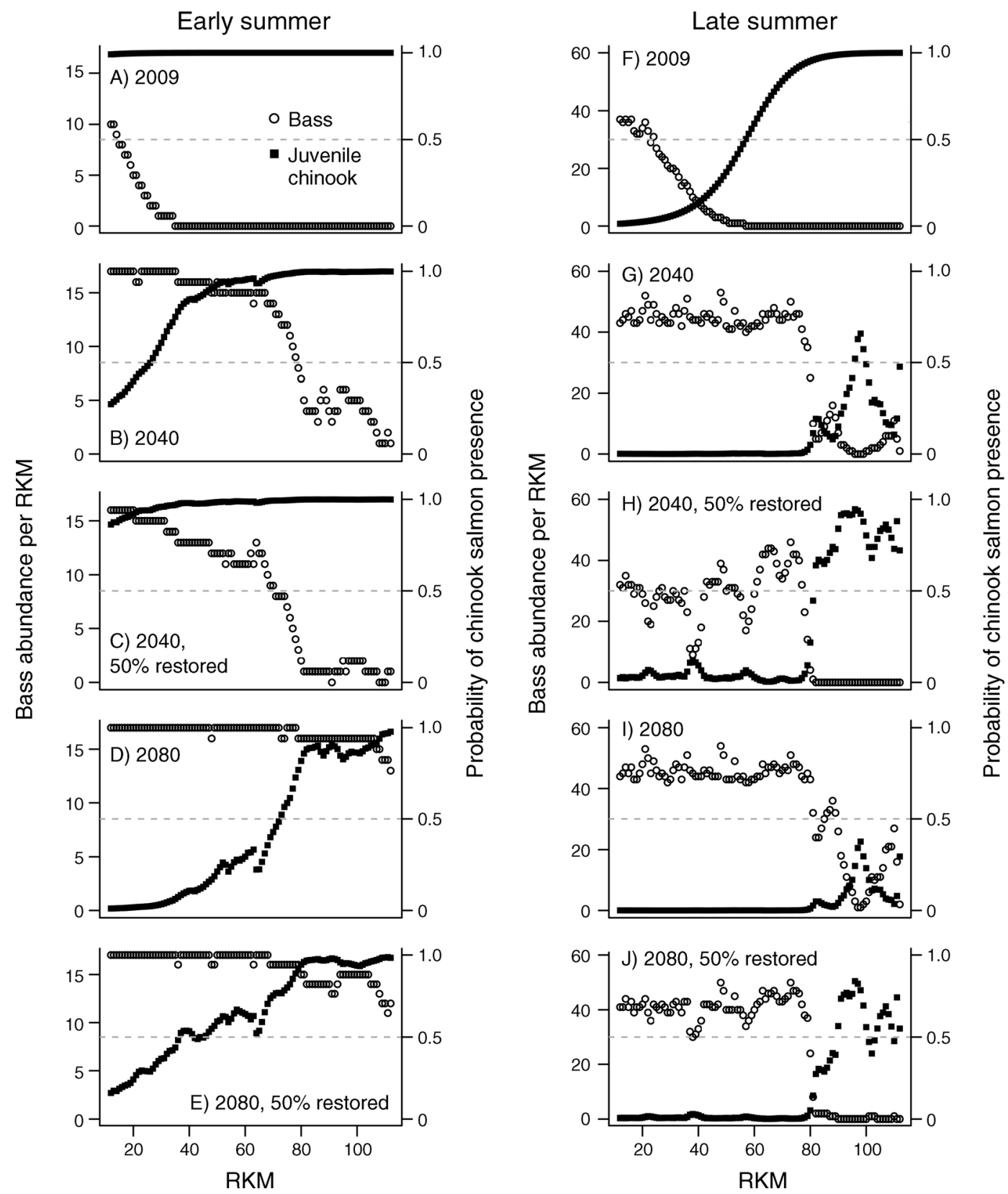

FIG. 3. Modeled bass and subyearling (juvenile) chinook salmon distribution over the longitudinal profile of the MFJDR in early summer (A) 2009, (B) 2040, (C) 2040 with the top 50\% of segments restored, (D) 2080, and (E) 2080 with the top $50 \%$ of segments restored; and late-summer forecasts in (F) 2009, (G) 2040, (H) 2040 with the top 50\% of restoration segments restored, (I) 2080 , and (J) 2080 with the top $50 \%$ of restoration segments restored. The dashed gray line in each panel indicates the probability that subyearling chinook salmon presence equals 0.5 . RKM signifies river kilometer.

bass and chinook salmon in the NFJDR may nearly double from $23 \mathrm{~km}$ in 2009 to $39 \mathrm{~km}$ by 2040, and nearly triple to $62 \mathrm{~km}$ by 2080. In the MFJDR, early-summer overlap between bass and subyearling chinook salmon may nearly quadruple from $23 \mathrm{~km}$ in 2009 to $86 \mathrm{~km}$ by 2040 , but then may decrease to $40 \mathrm{~km}$ by 2080 , as the distribution of subyearling chinook salmon becomes constrained to the upper river.
As was observed in 2009 (Figs. 2F and 3F), latesummer overlap between bass and subyearling chinook salmon by 2040 and 2080 is minimal in the NFJDR (Fig. $2 \mathrm{G}, \mathrm{I}$ ) and the MFJDR (Fig. 3G, I). As bass move upstream by 2040 and even farther upstream by 2080, so do subyearling chinook salmon, and therefore their overall overlap may not change. In the MFJDR, there is some potential for co-occurrence between bass and 


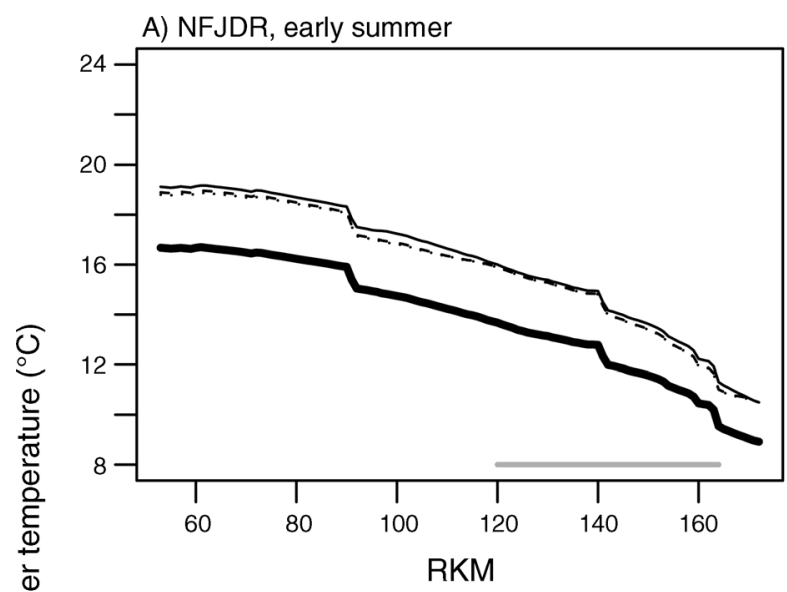

B) NFJDR, late summer

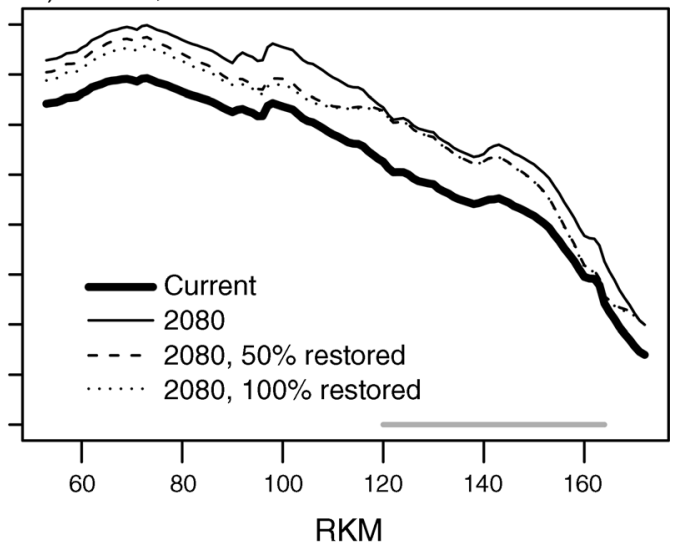

C) MFJDR, early summer

D) MFJDR, late summer
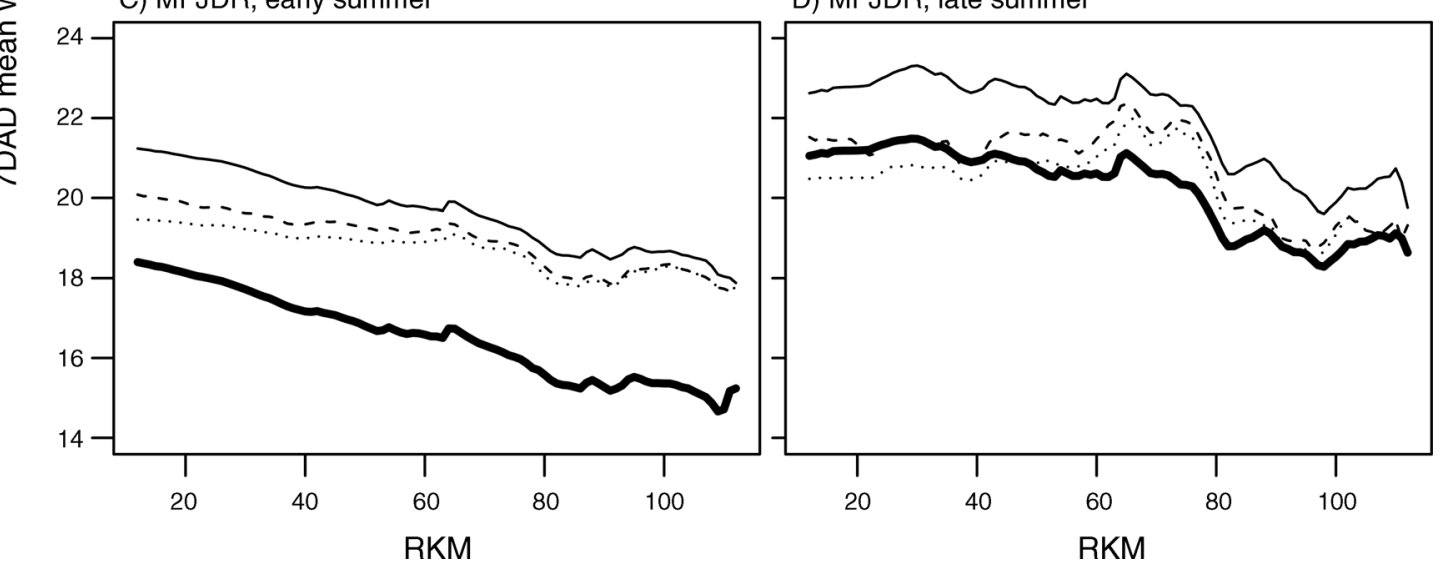

FIG. 4. Seven-day-average-daily (7DAD) mean water temperature along the longitudinal continuum for the current condition, 2080, and 2080 with $50 \%$ and $100 \%$ restoration for the NFJDR in (A) early summer and (B) late summer, and the MFJDR in (C) early summer and (D) late summer. The gray horizontal line in panels (A) and (B) from river kilometer (RKM) 120 to 164 represents an existing conservation area where vegetation is already considered to be at maximum height and density; therefore restoration was not considered there.

subyearling chinook salmon in the upper river (RKM $\geq$ 77 ), but in all reaches where bass are predicted to be present, the probability of chinook salmon presence is $<0.5$.

\section{Restoration of riparian vegetation to reduce stream temperatures}

The restoration of streamside vegetation had a relatively small capacity to lower early summer 7DAD mean temperatures of the NFJDR in 2080 (Fig. 4A). Riparian restoration in the NFJDR resulted in a relatively greater reduction in 7DAD mean temperatures in late summer (Fig. 4B), with a maximum reduction of $1.6^{\circ} \mathrm{C}$ (average reduction, $0.8^{\circ} \mathrm{C}$ ) given $100 \%$ restoration. Complete restoration of the NFJDR riparian corridor in 2080 in either season was not capable of achieving the 7DAD mean temperatures modeled for 1977-2006 (Fig. 4A, B).

Restoration had a more pronounced effect on stream temperature in the MFJDR (Fig. 4C, D). Similar to the NFJDR, riparian restoration resulted in greater reduc- tions in 7DAD mean temperatures in the late summer compared to the early summer. The maximum reductions in early summer 7DAD mean temperatures achievable by complete restoration of the MFJDR riparian zone was $1.8^{\circ} \mathrm{C}$ (mean $\left.1.0^{\circ} \mathrm{C}\right)$, where the greatest effect of restoration on temperature was observable in the downstream reaches of the river (Fig. 4C). In the late summer, restoration was effective at reducing temperatures in both the lower and upper MFJDR, with a maximum capacity to reduce 7DAD mean temperatures by $2.5^{\circ} \mathrm{C}$ (mean $1.6^{\circ} \mathrm{C}$ ) under complete riparian vegetation restoration (Fig. 4D). No amount of riparian restoration was capable of achieving the 7DAD mean temperatures modeled during the early-summer current condition (Fig. 4C). However, restoring 50\% of the MFJDR by 2080 is forecasted to decrease water temperatures to what they were in 1977-2006 in the lower river during late summer (Fig. 4D). Riparian restoration along the entire MFJDR by 2080 lowered the 7DAD mean water temperature below the 19772006 average in downstream areas in late summer 
A) NFJDR, early summer

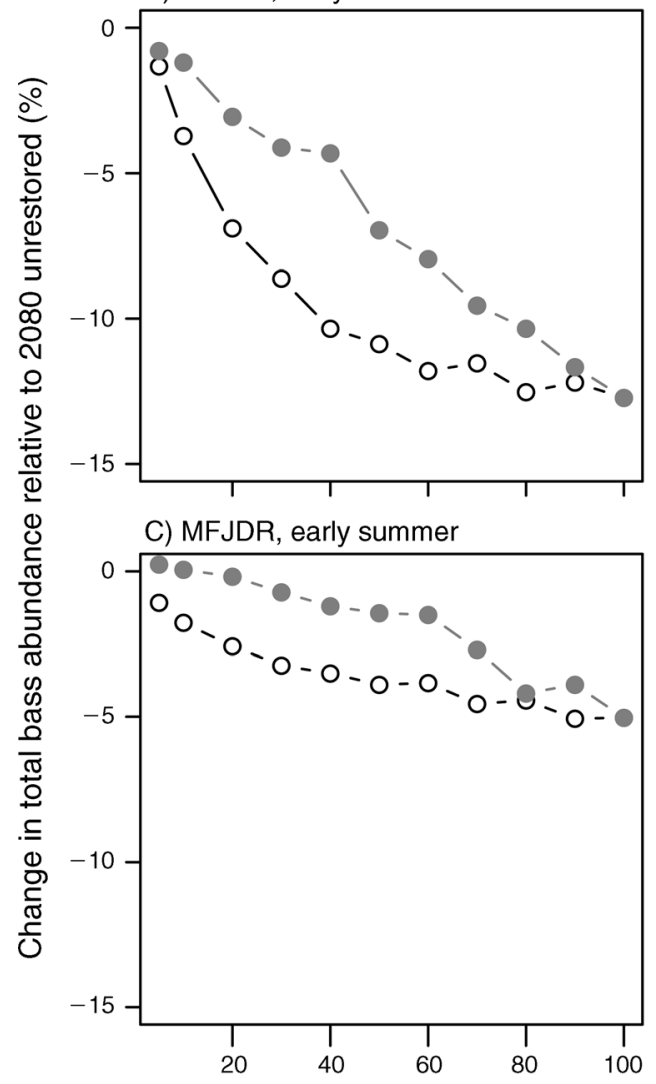

B) NFJDR, late summer

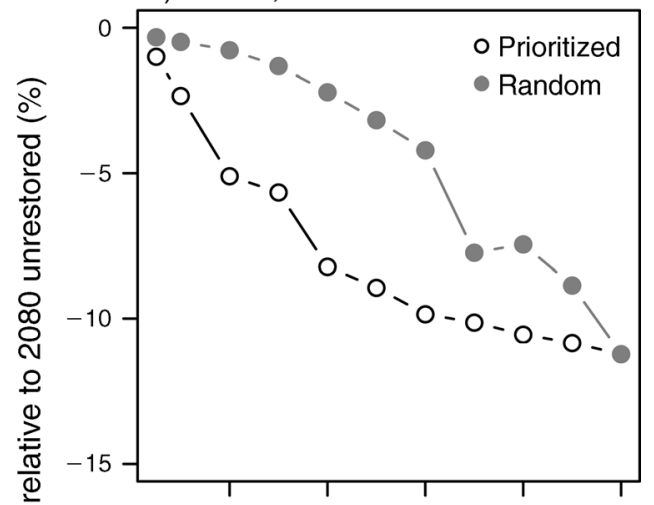

D) MFJDR, late summer

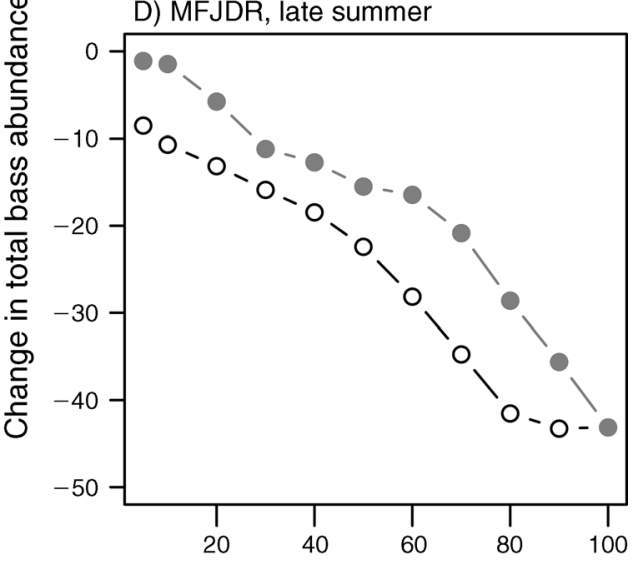

Level of restoration (\%)

FIG. 5. Change in the total bass abundance (i.e., over the entire model domain) in 2080 with increasing levels of riparian restoration for the NFJDR in (A) early summer and (B) late summer, and the MFJDR in (C) early summer and (D) late summer. Open circles indicate prioritized restoration for a given level of restoration (from 5\% to 100\%) where segments that resulted in the greatest enhancement of effective shade were restored first. Solid circles indicate that restored segments were chosen randomly.

( $<$ RKM 50), but this was not the case in the upper river (Fig. 4D). This is likely due to the greater scope for increasing effective shade in downstream portions of the MFDJR relative to some upstream areas in that basin (Appendix C: Fig. C1).

\section{The influence of riparian restoration on fish distributions}

The restoration of riparian areas indirectly influenced bass and chinook salmon distributions through modification of stream temperatures. The capacity of restoration to reduce the abundance and upstream extent of bass by 2080 was lower in the NFJDR (Figs. 2 and 5A, B) compared to the MFJDR (Figs. 3 and 5C, D). This illustrates the limited capacity of riparian restoration to reduce 7DAD mean water temperatures within the NFJDR relative to the MFJDR. In the NFJDR, $50 \%$ restoration of riparian vegetation by 2080 slightly reduced the early-summer upstream expansion of bass, thereby lowering their upstream-most occurrence to RKM 109 (Fig. 2E), compared to RKM 114 in the unrestored condition (Fig. 2D). Restoration did not reduce the upstream extent of bass in the late summer in the NFJDR (Fig. 2I vs. 2J). The overall abundance of bass in the NFJDR decreased with increasing restoration (Fig. 5A, B). Complete restoration of the riparian corridor by 2080 was capable of reducing the overall abundance of bass in the NFJDR by up to $13 \%$ in the early summer (Fig. 5A), and $11 \%$ in the late summer (Fig. 5B). In the MFJDR, restoration of $50 \%$ of the landscape is not likely to reduce the upstream extent of bass in the early summer of the 2080s (Fig. 3E), but it is likely to prevent large numbers of bass from moving into the upper river in the late summer. Bass are forecasted to occupy the entire MFJDR in late summer by 2080 (Fig. 3I), but simulations of $50 \%$ restoration restricted bass from most of the upper $31 \mathrm{~km}$ of river (>RKM 81; Fig. $3 \mathrm{~J})$. Restoration reduced the overall abundance of bass in the MFJDR in the 2080 s by up to $5 \%$ in the early summer (i.e., $100 \%$ vs. $0 \%$ restoration of the MFJDR in 2080; Fig. 5C), and resulted in up to a $43 \%$ reduction in overall bass abundance in the late summer of the $2080 \mathrm{~s}$ (Fig. 5D). In both the NFJDR and MFJDR, restoration in specific "priority" areas outperformed random 
A) NFJDR, early summer

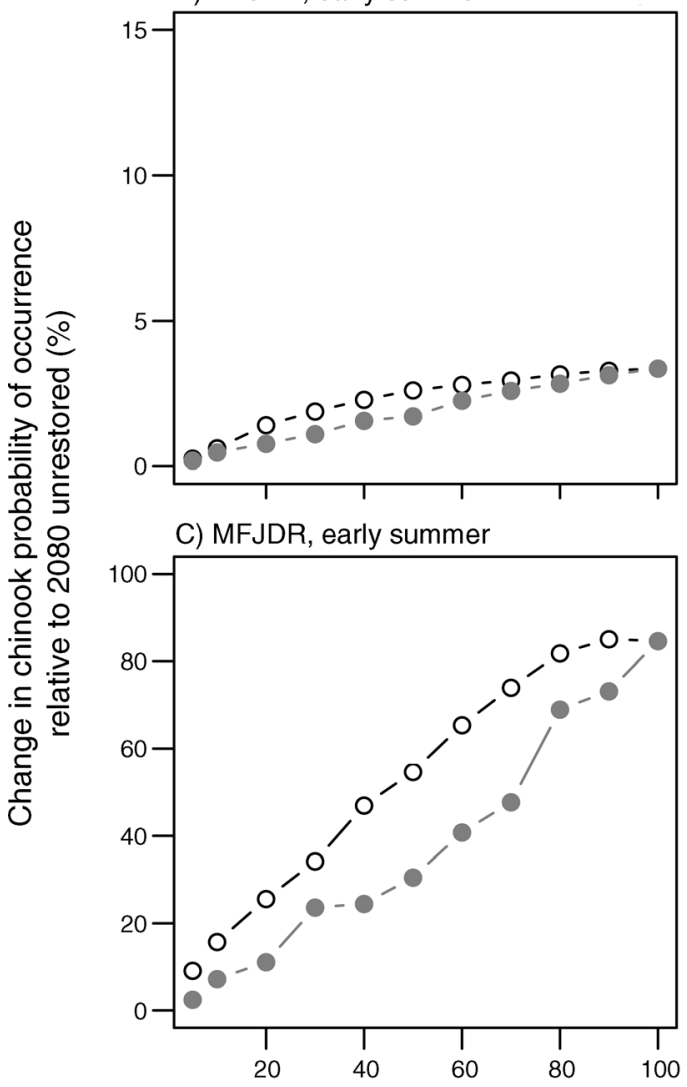

B) NFJDR, late summer

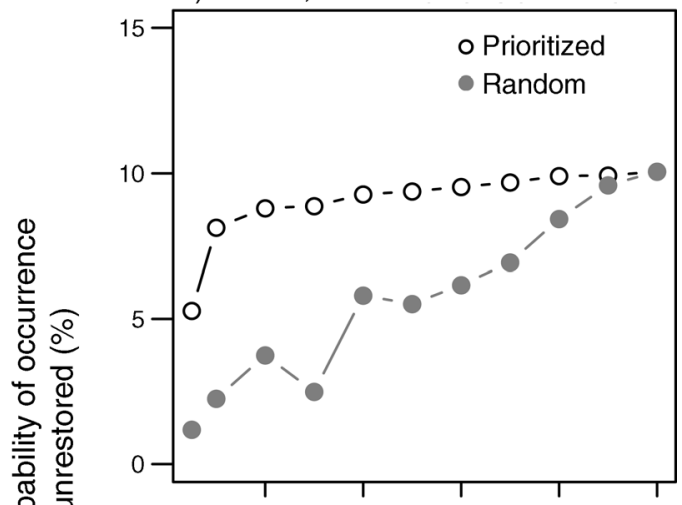

D) MFJDR, late summer

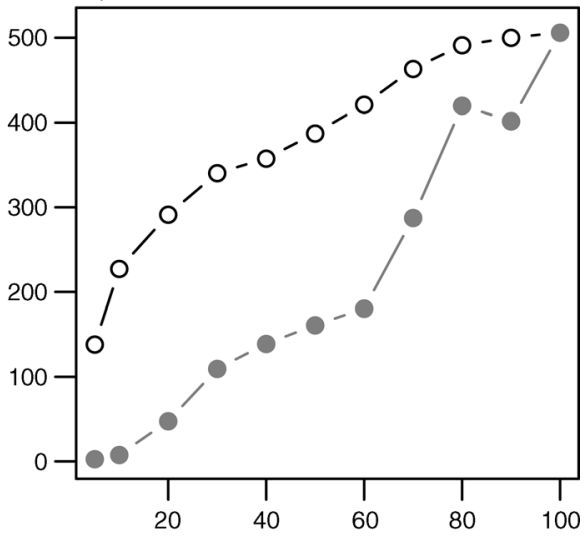

Level of restoration (\%)

FIG. 6. Change in the subyearling chinook salmon probability of occurrence (summed over the entire model extent) in 2080 with increasing levels of riparian restoration for the NFJDR in (A) early summer and (B) late summer, and the MFJDR in (C) early summer and (D) late summer. Open circles indicate prioritized restoration for a given level of restoration (from 5\% to $100 \%$ ) where segments that resulted in the greatest enhancement of effective shade were restored first. Solid circles indicate that restored segments were chosen randomly.

restoration in reducing the overall abundance of bass for a given level of restoration investment (Fig. 5).

The effect of restoration on subyearling chinook salmon occurrence was most apparent in the MFJDR where the potential for increasing streamside shade was greater. In the NFJDR, thermally suitable habitat for subyearling chinook salmon occurred throughout the river in the early summer of the 2080s, with or without restoration (Fig. 2D, E). Increasing amounts of restoration increased the overall probability of chinook salmon occurrence in the NFJDR by up to $3 \%$ during early summer (Fig. 6A) and up to $10 \%$ in late summer (Fig. 6B). In the MFJDR, 50\% restoration increased the amount of thermally suitable habitat for subyearling chinook salmon by $36 \mathrm{~km}$ in the early summer of the 2080s ( RKM $\geq 37$ compared to $\mathrm{RKM} \geq 73$ in the unrestored condition; Fig. 3D, E). During this period, the overall probability of subyearling chinook salmon occurrence increased by up to $85 \%$ through restoration (Fig. 6C). In the late summer of the 2080s, thermally suitable rearing habitat in the MFJDR is totally unavailable to subyearling chinook salmon without restoration (Fig. 3I); however, restoration of $50 \%$ of the riparian corridor may provide $19 \mathrm{~km}$ of the MFJDR (upstream of RKM 90) that is available for rearing (Fig. $3 \mathrm{~J})$. Restoration of the MFJDR resulted in a $506 \%$ increase in the probability of subyearling chinook salmon occurrence in the late summer of the 2080s compared to no restoration (Fig. 6D). In both tributaries, prioritized restoration had a greater effect on the probability of subyearling chinook salmon presence than random restoration (Fig. 6), but this effect was most apparent in the MFJDR (Fig. 6C, D).

The effect of restoration on the overlap between bass and subyearling chinook salmon was variable for the NFJDR and MFJDR. In the NFJDR, restoration decreased the extent of overlap between bass and subyearling chinook salmon by $5 \mathrm{~km}$ in the early summer of the 2080s, and increased the probability of chinook salmon where they co-occurred (Fig. 2D, E). In the MFJDR, the spatial extent of early-summer overlap of bass and chinook salmon increased with restoration 
by 2080 , but this mainly reflected an overall increase in the probability of subyearling chinook salmon presence rather than a shift in bass upstream extent (Fig. 3D, E). Late summer co-occurrence of bass and subyearling chinook salmon by 2080 was minimal with no restoration in the NFJDR and MFJDR; however, restoration may prevent bass from occupying the upper MFJDR and increase the capacity of these areas to support subyearling chinook salmon (Fig. 3I, J).

\section{Discussion}

The forecasts of climate change presented in our study suggest that extensive stream warming by the middle and end of this century will allow nonnative bass to occupy an increasingly large portion of tributaries within the John Day River (JDR) basin, and subyearling chinook salmon-rearing habitat will be reduced. This pattern is likely to be repeated in streams throughout the Pacific Northwest where temperatures are forecasted to increase (Isaak et al. 2012) and where bass are widely introduced (Carey et al. 2011). The forecasts are particularly severe for the Middle Fork of the JDR (MFJDR), where rearing habitat for subyearling chinook salmon (without riparian restoration) will nearly disappear if the 2080 projections of climate change occur. The losses in salmonid habitat projected for the JDR basin and the broader interior Columbia River basin represent some of the highest potential declines in the range of chinook salmon. This region is part of the southern extent of chinook salmon distribution, where the contemporary climate regularly approaches (and sometimes exceeds) the thermal tolerances of the species (Mantua et al. 2010).

Our study is one of the first attempts to forecast interactions between bass and chinook salmon distribution based on seasonal water temperature patterns and climate change. Based on our 2009 surveys, we observed that the early- and late-summer period correspond to different degrees of sympatry between these fishes. The early summer is a time of high overlap between bass and subyearling chinook salmon. This overlap most likely occurs because subyearling chinook salmon disperse downstream after emergence in March to June due to displacement from high spring flows, displacement for upstream feeding sites resulting from intraspecific competition, or purposeful downstream movement (Murray and Rosenau 1989, Bradford and Taylor 1997). In the North Fork (NFJDR) and MFJDR, subyearling chinook salmon are commonly observed downstream of their downstream-most spawning sites (Lindsay et al. 1985). In these downstream nonnatal areas, bass emerge from winter torpor as temperatures rise from $10^{\circ}$ to $15^{\circ} \mathrm{C}$ and begin building nests in anticipation of spawning (Armour 1993). At this time, water temperatures are still cool enough to allow for occupancy by chinook salmon but not so cold that they prevent bass from occupying the area and nesting. As summer temperatures increase, subyearling chinook salmon vacate warm areas, moving upstream or into cooler tributaries, or are lost to predation. Some bass also move upstream (as documented by Lawrence et al. 2012) but not far enough to maintain the relatively high degree of overlap observed between bass and subyearling chinook salmon in the early summer. It is likely that the much warmer stream temperatures observed during the late summer isolate bass and subyearling chinook salmon due to physiological differences in thermally mediated growth and consumption. Thus the relative extent of overlap between bass and chinook salmon is much lower in late summer compared to early summer.

We forecast that sympatry between bass and subyearling chinook salmon will increase dramatically in the early summer as streams warm through the 2040s and 2080s. In the NFJDR, increases in water temperature in the early summer were enough for bass to significantly expand in upstream distribution, but not great enough to restrict subyearling chinook salmon from occupying the lower extents of the modeled domain. Thus overlap in this system increased in the early-summer period by the 2040s and 2080s. In the MFJDR, forecasted warming in the early summer enabled bass to occupy the entire modeled extent of the river. The warming achieved by 2040 , however, does not exclude subyearling chinook salmon from occupying much of the lower MFJDR. Therefore, overlap between bass and rearing chinook salmon is likely to be high during the early summer in the 2040s. However, as early summer warming progresses into the 2080s, the degree of warming is such that a large fraction of the habitat will become thermally unsuitable for subyearling chinook salmon. Thus the spatial overlap between bass and chinook salmon will decrease. This difference leads to the counterintuitive result that as the riparian zone of the MFJDR is restored by the 2080s (and water temperatures are lowered) the expected overlap between bass and chinook salmon in the early summer increases. In this situation, the degree of cooling achieved through the restoration in the MFJDR is enough to enhance the probability of subyearling chinook salmon presence, but may not be enough to prevent bass from occupying the upper river. In the late summer, bass are forecasted to advance farther into previously suitable chinook salmon-rearing habitat in both river systems. In the late summer, however, warm water temperatures maintain spatial separation between bass and chinook salmon, i.e., the relatively minimal amount of overlap observed between these fishes in 2009 is maintained by the 2040s and 2080s because both species move upstream as temperatures warm in the late summer. In the case of subyearling chinook salmon, they have a limited distance to move upstream before reaching ephemeral headwater areas. Thus even though the sympatry between bass and subyearling chinook salmon did not increase as bass moved farther upstream by 2080, the total thermally suitable habitat available to subyearling chinook salmon decreased significantly (i.e., $34 \mathrm{~km}$ in 
the NFJDR, a $55 \%$ reduction; $56 \mathrm{~km}$ in the MFJDR, a $100 \%$ reduction).

In addition to the large increases in bass upstream extent forecasted over the next century, the overall abundance of bass is also forecasted to increase within the NFJDR and MFJDR. A broader degree of earlyseason overlap combined with larger numbers of bass in chinook salmon-rearing areas may enhance predation of bass on subyearling chinook salmon. The extent to which bass consume subyearling chinook salmon in the upper JDR basin is not known, but bass have been shown to feed heavily on small subyearling chinook salmon when they co-occur in the Yakima River system (Fritts and Pearsons 2004). Fritts and Pearsons (2004) attributed this degree of predation to both the small size of rearing chinook salmon when they overlap with bass and the relatively warm stream temperatures during their co-occurrence that stimulate bass metabolism and thus consumption. Similarly, in the NFJDR and MFJDR, bass overlap with subyearling chinook salmon that are comparable in size to those observed in the Yakima River, and this overlap occurs when water temperatures are warm enough to enable bass feeding. Subyearling chinook salmon may be particularly vulnerable because they do not initially recognize bass as predators, an oversight resulting from a lack of shared evolutionary history between predator and prey (Kuehne and Olden 2012). Bass may also have sublethal effects on subyearling chinook salmon by causing stress and inhibiting feeding and growth (Kuehne et al. 2012).

The carrying capacity of streams to support bass may also change in the future, although we did not address this change in our model structure. The total number of bass forecasted to occupy the study system is determined partly by the observed carrying capacity of bass, as parameterized in the bass model with 2009 and 2010 data. However, the carrying capacity could increase as temperatures warm by enhancing the overwinter survival of bass, or through demographic processes such as increased reproduction. If the carrying capacity of bass increases as the NFJDR and MFJDR warm, then it is possible that our future estimates of bass abundances are conservative, especially in the lower river where bass are forecasted to reach the model carrying capacity over large spatial extents. One important caveat is that food availability may limit increases in bass carrying capacity, but the extent to which stream productivity will increase as temperatures increase is still unclear. Ultimately, accounting for these potential changes in carrying capacity would require a deterministic demographic model (e.g., Peterson and Kwak 1999). Such models represent an avenue for future research when forecasting bass populations that occupy salmon-bearing streams, but they require more data than statistical models.

Other stream variables may also determine how bass and subyearling chinook salmon populations respond to climate change, depending on the context of the river system. For example, we accounted for alterations in stream flow associated with climate change in terms of its influence on stream temperature, but we did not model the direct effects of changing stream discharge on bass and subyearling chinook salmon. In the Pacific Northwest, many snow-melt systems (such as the tributaries presented in this study) are predicted to become rain-dominated systems over the next century (Elsner et al. 2010, Reidy Liermann et al. 2012). This change from relatively predictable and gradual declines in flow to more rapid stream discharge could have direct effects on bass spawning nests and fry, which are susceptible to scour and may be displaced under high flows (Smith et al. 2005). The transition from snow to rain-dominated systems can also have direct negative consequences on salmon recruitment if the winter discharge is large enough to mobilize the stream bed and scour salmon eggs residing in the substrate (Goode et al. 2013). Additionally, geomorphic features may limit the upstream intrusion of bass in mountainous river systems, even if these areas are thermally suitable. For example, high-gradient segments of rivers are common in upstream reaches, and these areas may not be accessible by bass. The extent to which bass can move through high-gradient segments, especially at high flow, is unknown at this time (Lawrence et al. 2012). Also, stream substrates change longitudinally, and therefore, as bass move upstream, they may have difficulty finding appropriately sized spawning gravels (Lukas and Orth 1995, Dauwalter and Fisher 2007). Differences in basin productivity, due to geology and land use could also lead to different responses to climatic trends by bass and chinook salmon, given that their thermal tolerances are also contingent on food supply (Beauchamp 2009). Together, these factors could be incorporated into future efforts to predict the response of bass and chinook salmon to climate change.

Restoring riparian vegetation may offset climateinduced losses in thermally suitable chinook salmonrearing habitat and may reduce the expansion of bass into upstream habitats. Riparian restoration may be particularly useful in small to mid-sized streams (fifth order or smaller) if shade provided by riparian vegetation is the primary determinant of stream temperature (Johnson 2004, Cristea and Burges 2010). Our results showed that the capacity of restoration to offset some of the warming forecasted by the 2080s varied by both season (i.e., early vs. late summer) and by stream (i.e., NFJDR vs. MFJDR). In both streams, restoration had a greater capacity to reduce late-summer temperatures compared to early-summer temperatures. This is likely because stream flow declines seasonally, and by late summer these streams are shallower and more prone to warming, a time when riparian shading has the greatest potential to provide a cooling benefit.

Riparian restoration had a greater potential to reduce stream temperatures forecasted for the 2080s in the MFJDR than the NFJDR, and given its potential cost, restoration may have a greater return on investment if 
employed there. The upper NFJDR has a largely intact riparian corridor and therefore has a smaller capacity to increase effective shade than the MFJDR (i.e., there is a relatively small difference between current and potential effective shade in the NFJDR; Appendix C). Additionally, the lower NFJDR has a smaller total magnitude of restored effective shade compared to the lower MFJDR (Appendix C: Fig. C1). This is likely the result of (1) smaller channel widths in the MFJDR, which allow for more effective shading of the stream if restored; and (2) differences in the ecoregions and physiographic regions between these stream systems, which in turn influence the tree heights in the riparian canopy and the foliage density predicted after restoration (see Appendix $\mathrm{C}$ for details). Cristea and Burges (2010) found a similar pattern when they investigated the potential for riparian vegetation restoration to offset climate-induced temperature increases in the Wenatchee River system in Washington; narrower streams could achieve greater effective shade after restoration and thus resulted in greater shade-related temperature decreases compared to larger streams. In the MFJDR there are many opportunities to increase stream shade because most riparian areas have been heavily grazed by either current or past ranching activities (Beschta and Ripple 2005) and disturbed by historical dredge mining. Parts of the upper MFJDR are currently undergoing riparian restoration as well as other forms of restoration, including stream channel re-meandering. Hydrology also plays an important role in determining thermal regimes (Caissie 2006). For example, reducing irrigation-related water removals has the capacity to reduce stream temperature, especially during summer baseflow conditions. The relative magnitude of benefits from streamflow and riparian vegetation restoration are likely to be system specific. In the MFJDR, ORDEQ (2010a) estimated that vegetation restoration had a greater capacity to reduce stream temperature compared to flow restoration. Despite this, instream flow restoration will certainly be a valuable stream temperature restoration tool in many systems in the Pacific Northwest (Beechie et al. 2013).

In our study, prioritized restoration outperformed opportunistic restoration in providing the dual benefit of reducing bass abundance and increasing the probability of subyearling chinook salmon occurrence. The priority restoration segments we identified (Appendix C: Figs. $\mathrm{C} 2$ and $\mathrm{C} 3$ ) could be used to allocate limited restoration funds to the segments where restoration would have the biggest ecological benefit for salmon. If our forecasts of stream warming by the 2080s occur, restoration will likely be the only way to prevent extirpation of spring chinook salmon from the MFJDR. Another important consideration in evaluating the effectiveness of restoration in mitigating climate change is that the magnitude of stream temperature reduction achievable through restoration depends partly on the metric used to define temperature. We used the 7-day-average-daily (7DAD) mean, but if we had used 7DAD maximum, greater reductions in stream temperature may have been observed. This pattern has been shown experimentally by shading streams (Johnson 2004). Although reductions in the 7DAD mean temperature may be relatively small for the NFJDR, a greater reduction in the 7DAD maximum may be achievable through restoration.

There are uncertainties associated with forecasts of global warming, and these uncertainties have to be considered when prioritizing adaptation strategies. For example, Arismendi et al. (2012) showed that some streams become cooler even when the regional climate trends reflect overall warming. Additionally, the general circulation model that we downscaled is one of many projections of climate change available for the region. Lawler et al. (2010) suggest that it is important to use low-risk adaptation strategies that are robust to this uncertainty; that is, they benefit the ecosystem even if the exact magnitude of warming is unknown. In stream systems, riparian restoration provides one such low-risk adaptation strategy because riparian vegetation also provides coarse-woody habitat and terrestrial food subsidies to streams (Wipfli and Baxter 2010). Restored riparian vegetation also retains sediment, stabilizes banks, and reduces erosion (Beechie et al. 2013). These changes may have an additional cooling effect not currently considered in our modeling approach.

Climate-induced stream warming is likely to occur throughout the interior Western United States and other regions in the United States and the world (Poff et al. 2002, Wenger et al. 2011). In our study, we provide a mechanism to translate regional-scale climate forecasts into local-scale changes in fish distribution. The stream temperature model we employed was mechanistic and spatially explicit and therefore provided a means to evaluate the extent to which riparian restoration can ameliorate warming. We believe this approach could be applied in many other streams where the data inputs are already available (i.e., downscaled climate forecasts, stream temperature models, fish-temperature relationships).

Climate change affects species directly and indirectly through myriad stressors that are already present in the ecosystem (Nelson et al. 2009). For example, additional warming in the MFJDR (a river system that is currently considered thermally impaired due to riparian vegetation removal) may result in the extirpation of the chinook salmon unless riparian restoration is undertaken to increase shade and offset the impacts of climate change. This outcome is starkly different from that projected for the NFJDR where a relatively intact riparian corridor supports cool water habitat, even in the face of climate-induced stream warming. Climate change will also affect stream-rearing salmon by enabling the range expansion of predatory nonnative species such as bass. The interactive effects of climate change, riparian land use, and introduced species will determine the future of rearing salmon populations. This 
work highlights the potential for restoration to mitigate some of the effects of climate change, especially in systems with a high degree of current riparian vegetation alteration and spreading nonnative species.

\section{ACKNOWLEDGMENTS}

We thank Seth Wenger for providing the downscaled flow forecasts and Marketa Elsner and Guillaume Mauger for providing the downscaled general circulation model products. Carol Volk and Aaron Maxwell provided some of the water temperature data used in this work. This paper was improved by input from Dave Beauchamp and two anonymous reviewers. Funding for this work was provided by the U.S. EPA Science to Achieve Results (STAR) program (grant \# 833834) and a Northwest Climate Science Center graduate fellowship awarded to D. J. Lawrence. Additional funding and support was provided by the USGS Forest and Rangeland Ecosystem Science Center. Any use of trade, product, or firm names is for descriptive purposes only and does not imply endorsement by the United States government.

\section{Literature Cited}

Arismendi, I., S. L. Johnson, J. B. Dunham, R. Haggerty, and D. Hockman-Wert. 2012. The paradox of cooling streams in a warming world: regional climate trends do not parallel variable local trends in stream temperature in the Pacific continental United States. Geophysical Research Letters 39:L10401.

Armour, C. L. 1993. Evaluating temperature regimes for protection of smallmouth bass. Resource Publication 191. United States Department of the Interior, Fish and Wildlife Service, Washington, D.C., USA.

Beauchamp, D. A. 2009. Bioenergetic ontogeny: linking climate and mass-specific feeding to life-cycle growth and survival of salmon. American Fisheries Society Symposium 70:1-19.

Beechie, T., et al. 2013. Restoring salmon habitat for a changing climate. River Research and Applications. http:// dx.doi.org/10.1002/rra. 2590

Beer, W. N., and J. J. Anderson. 2011. Sensitivity of juvenile salmonid growth to future climate trends. River Research and Applications 27:663-669.

Beschta, R. L., and W. J. Ripple. 2005. Rapid assessment of riparian cottonwood recruitment: Middle Fork John Day River, Northeastern Oregon. Ecological Restoration 23:150156.

Boone, E. L., B. Stewart-Koster, and M. J. Kennard. 2012. A hierarchical zero-inflated Poisson regression model for stream fish distribution and abundance. Environmetrics 23:207-218.

Boyd, M., and B. Kasper. 2003. Analytical methods for dynamic open channel heat and mass transfer: methodology for heat source model. Version 7.0. Oregon Department of Environmental Quality, Portland, Oregon, USA. http:// www.deq.state.or.us/wq/tmdls/docs/tools/heatsourcemanual. pdf

Bradford, M. J., and G. C. Taylor. 1997. Individual variation in dispersal behaviour of newly emerged chinook salmon (Oncorhynchus tshawytscha) from the upper Fraser River, British Columbia. Canadian Journal of Fisheries and Aquatic Sciences 54:1585-1592.

Caissie, D. 2006. The thermal regime of rivers: a review. Freshwater Biology 51:1389-1406.

Carey, M. P., B. L. Sanderson, T. A. Friesen, K. A. Barnas, and J. D. Olden. 2011. Smallmouth bass in the Pacific Northwest: a threat to native species; a benefit for anglers. Reviews in Fisheries Science 19:305-315.

Cristea, N. C., and S. J. Burges. 2010. An assessment of the current and future thermal regimes of three streams located in the Wenatchee River basin, Washington State: some implications for regional river basin systems. Climatic Change 102:493-520.

Dauwalter, D. C., and W. L. Fisher. 2007. Spawning chronology, nest site selection and nest success of smallmouth bass during benign streamflow conditions. American Midland Naturalist 158:60-78.

Elsner, M., L. Cuo, N. Voisin, J. Deems, A. Hamlet, J. Vano, K. Mickelson, S.-Y. Lee, and D. Lettenmaier. 2010. Implications of 21 st century climate change for the hydrology of Washington State. Climatic Change 102:225-260.

Fritts, A. L., and T. N. Pearsons. 2004. Smallmouth bass predation on hatchery and wild salmonids in the Yakima River, Washington. Transactions of the American Fisheries Society 133:880-895.

Gelman, A., J. B. Carlin, H. S. Stern, and D. B. Rubin. 2004. Bayesian data analysis. Second edition. Chapman and Hall, Boca Raton, Florida, USA.

Goode, J. R., J. M. Buffington, D. Tonina, D. J. Isaak, R. F. Thurow, S. Wenger, D. Nagel, C. Luce, D. Tetzlaff, and C. Soulsby. 2013. Potential effects of climate change on streambed scour and risks to salmonid survival in snowdominated mountain basins. Hydrological Processes 27:750765 .

Gordon, A. D., and H. T. B. Birks. 1972. Numerical methods in Quaternary palaeoecology. I. Zonation of pollen diagrams. New Phytologist 71:961-979.

Grimm, E. C. 1987. CONISS: a FORTRAN 77 program for stratigraphically constrained cluster analysis by the method of incremental sum of squares. Computers and Geosciences 13:13-35.

Hamlet, A. F., et al. 2010. Final project report for the Columbia Basin Climate Change Scenarios Project. Climate Impacts Group, University of Washington, Seattle, Washington, USA. http://www.hydro.washington.edu/2860/report/

Hamlet, A. F., P. W. Mote, M. P. Clark, and D. P. Lettenmaier. 2007. Twentieth-century trends in runoff, evapotranspiration, and soil moisture in the western United States. Journal of Climate 20:1468-1486.

Hosmer, D. W., and S. Lemeshow. 2000. Applied logistic regression. Wiley, New York, New York, USA.

IPCC (Intergovernmental Panel on Climate Change). 2007. Climate change 2007: impacts, adaptation and vulnerability. Contribution of Working Group II to the Fourth Assessment Report of the Intergovernmental Panel on Climate Change. Cambridge University Press, Cambridge, UK.

Isaak, D. J., S. Wollrab, D. Horan, and G. Chandler. 2012. Climate change effects on stream and river temperatures across the northwest U.S. from 1980-2009 and implications for salmonid fishes. Climatic Change 113:499-524.

Johnson, S. L. 2004. Factors influencing stream temperatures in small streams: substrate effects and a shading experiment. Canadian Journal of Fisheries and Aquatic Sciences 61:913923.

Juggins, S. 2012. Analysis of quaternary science data. R package 'rioja' version 0.7-3. Newcastle University, Newcastle, UK. http://cran.r-project.org/web/packages/rioja/ index.html

Kaushal, S. S., G. E. Likens, N. A. Jaworski, M. L. Pace, A. M. Sides, D. Seekell, K. T. Belt, D. H. Secor, and R. L. Wingate. 2010. Rising stream and river temperatures in the United States. Frontiers in Ecology and the Environment 8:461-466.

Kuehne, L., and J. D. Olden. 2012. Prey naivety in the behavioural responses of juvenile chinook (Oncorhynchus tshawytscha) salmon to an invasive predator. Freshwater Biology 57:1126-1137.

Kuehne, L. M., J. D. Olden, and J. J. Duda. 2012. Costs of living for juvenile chinook salmon (Oncorhynchus tshawytscha) in an increasingly warming and invaded world. Canadian Journal of Fisheries and Aquatic Sciences 69:1621-1630. 
Lawler, J. J., et al. 2010. Resource management in a changing and uncertain climate. Frontiers in Ecology and the Environment 8:35-43.

Lawrence, D. J., J. D. Olden, and C. E. Torgersen. 2012. Spatiotemporal patterns and habitat associations of smallmouth bass (Micropterus dolomieu) invading salmon-rearing habitat. Freshwater Biology 57:1929-1946.

Lindsay, R. B., W. J. Knox, M. W. Flesher, B. J. Smith, E. A. Olsen, and L. S. Lutz. 1985. Study of wild spring chinook salmon in the John Day River system. Oregon Department of Fish and Wildlife, Portland, Oregon, USA.

Littell, J. S., M. M. Elsner, G. S. Mauger, E. Lutz, A. F. Hamlet, and E. Salathe. 2011. Regional climate and hydrologic change in the Northern U.S. Rockies and Pacific Northwest: internally consistent projections of future climate for resource management. Preliminary project report, USFS JVA 09-JV-11015600-039. Prepared by the Climate Impacts Group, University of Washington, Seattle, Washington, USA. http://cses.washington.edu/picea/USFS/pub/Littell_ etal_2010/

Lukas, J. A., and D. J. Orth. 1995. Factors affecting nesting success of smallmouth bass in a regulated Virginia stream. Transactions of the American Fisheries Society 124:726-735.

Lunn, D., A. Thomas, N. Best, and D. J. Spiegelhalter. 2000. WinBUGS - a Bayesian modelling framework: concepts, structure, and extensibility. Statistics and Computing 10:325-337.

Mantua, N., I. Tohver, and A. Hamlet. 2010. Climate change impacts on streamflow extremes and summertime stream temperature and their possible consequences for freshwater salmon habitat in Washington State. Climatic Change 102:187-223.

Mote, P. W., and E. P. Salathé. 2010. Future climate in the Pacific Northwest. Climatic Change 102:29-50.

Murray, C. B., and M. L. Rosenau. 1989. Rearing of juvenile chinook salmon in nonnatal tributaries of the lower Fraser River, British Columbia. Transactions of the American Fisheries Society 118:284-289.

Naiman, R. J., et al. 2012. Developing a broader scientific foundation for river restoration: Columbia River food webs. Proceedings of the National Academy of Sciences USA. http://dx.doi.org/10.1073/pnas.1213408109

Nelson, K. C., M. A. Palmer, J. E. Pizzuto, G. E. Moglen, P. L. Angermeier, R. H. Hilderbrand, M. Dettinger, and K. Hayhoe. 2009. Forecasting the combined effects of urbanization and climate change on stream ecosystems: from impacts to management options. Journal of Applied Ecology 46:154-163.

ORDEQ (Oregon Department of Environmental Quality). 2010a. John Day River basin total maximum daily load (TMDL) and water quality management plan (WQMP). State of Oregon, Department of Environmental Quality, Portland, Oregon, USA.

ORDEQ (Oregon Department of Environmental Quality). 2010b. John Day River basin total maximum daily load (TMDL) Appendix C: estimate of natural potential vegetation in the John Day basin. State of Oregon, Department of Environmental Quality, Portland, Oregon, USA.

Peterson, J. T., and T. J. Kwak. 1999. Modeling the effects of land use and climate change on riverine smallmouth bass. Ecological Applications 9:1391-1404.

Poff, N. L., M. M. Brinson, and J. W. J. Day. 2002. Aquatic ecosystems and global climate change. Pew Center on Global Climate Change, Arlington, Virginia, USA.

Powell, R. M., P. D. Alley, L. Goin, and J. Kehrberg. 2008. John Day River Sub-basin Fish Habitat Enhancement Project. Annual report. Oregon Department of Fish and Wildlife, John Day, Oregon, USA.
R Development Core Team. 2013. R: a language and environment for statistical computing. R Foundation for Statistical Computing, Vienna, Austria.

Rahel, F. J., and J. D. Olden. 2008. Assessing the effects of climate change on aquatic invasive species. Conservation Biology 22:521-533.

Reidy Liermann, C. A., J. D. Olden, T. J. Beechie, M. J. Kennard, P. B. Skidmore, C. P. Konrad, and H. Imaki. 2012. Hydrogeomorphic classification of Washington state rivers to support emerging environmental flow management strategies. River Research and Applications 28:1340-1358.

Rieman, B. E., D. Isaak, S. Adams, D. Horan, D. Nagel, C. Luce, and D. Myers. 2007. Anticipated climate warming effects on bull trout habitats and populations across the interior Columbia River basin. Transactions of the American Fisheries Society 136:1552-1565.

Rieman, B. E., and D. J. Isaak. 2010. Climate change, aquatic ecosystems, and fishes in the Rocky Mountain West: implications and alternatives for management. General Technical Report RMRS-GTR-250. USDA Forest Service, Rocky Mountain Research Station, Fort Collins, Colorado, USA.

Ruckelshaus, M. H., P. Levin, J. B. Johnson, and P. M. Kareiva. 2002. The Pacific salmon wars: what science brings to the challenge of recovering species. Annual Review of Ecology and Systematics 33:665-706.

Ruesch, A., C. E. Torgersen, J. J. Lawler, J. D. Olden, E. E. Peterson, C. Volk, and D. J. Lawrence. 2012. Projected climate-induced habitat loss for salmonids in the John Day River network, Oregon, U.S.A. Conservation Biology 26:873-882.

Sanderson, B. L., K. A. Barnas, and A. M. Wargo Rub. 2009. Nonindigenous species of the Pacific Northwest: an overlooked risk to endangered salmon? BioScience 59:245-256.

Sharma, S., L. Herborg, and T. W. Therriault. 2009. Predicting introduction, establishment and potential impact of smallmouth bass. Diversity and Distributions 15:831-840.

Shrader, T., and M. E. Gray. 1999. Biology and management of John Day River smallmouth bass. Oregon Department of Fish and Wildlife, Portland, Oregon, USA.

Smith, S. M., J. S. Odenkirk, and S. J. Reeser. 2005. Smallmouth bass recruitment variability and its relation to stream discharge in three Virginia rivers. North American Journal of Fisheries Management 25:1112-1121.

Sturtz, S., U. Ligges, and A. Gelman. 2005. R2WinBUGS: a package for running WinBUGS from R. Journal of Statistical Software 12:1-16.

Torgersen, C. E., R. N. Faux, B. A. McIntosh, N. J. Poage, and D. J. Norton. 2001. Airborne thermal remote sensing for water temperature assessment in rivers and streams. Remote Sensing of Environment 76:386-398.

Torgersen, C. E., D. M. Price, H. W. Li, and B. A. McIntosh. 1999. Multiscale thermal refugia and stream habitat associations of chinook salmon in northeastern Oregon. Ecological Applications 9:301-319.

U.S. EPA. 2002. National water quality inventory: report to Congress, 2002 reporting cycle. Washington, D.C., USA.

Wenger, S. J., et al. 2011. Flow regime, temperature, and biotic interactions drive differential declines of trout species under climate change. Proceedings of the National Academy of Sciences USA 108:14175-14180.

Wipfli, M. S., and C. V. Baxter. 2010. Linking ecosystems, food webs, and fish production: subsidies in salmonid watersheds. Fisheries 35:373-387.

Woodward, G., D. M. Perkins, and L. E. Brown. 2010. Climate change and freshwater ecosystems: impacts across multiple levels of organization. Philosophical Transactions of the Royal Society B 365:2093-2106. 


\section{Supplemental Material}

\section{Appendix A}

Methods and data sources for future predictions of air temperature and tributary and boundary conditions input into the Heat Source stream temperature model (Ecological Archives A024-052-A1).

\section{Appendix B}

Forecasts of the longitudinal profile of stream temperature (7DAD mean) in the NFJDR and MFJDR during early and late summer (Ecological Archives A024-052-A2).

\section{Appendix C}

Comparison of the potential for riparian restoration to reduce stream temperature in the NFJDR and MFJDR, and figures showing the spatial location of prioritized riparian restoration in the NFJDR and MFJDR (Ecological Archives A024-052-A3). 